\title{
The Auckland School: 100 Years of Architecture and Planning. Edited by Julia Gatley and Lucy Treep
}

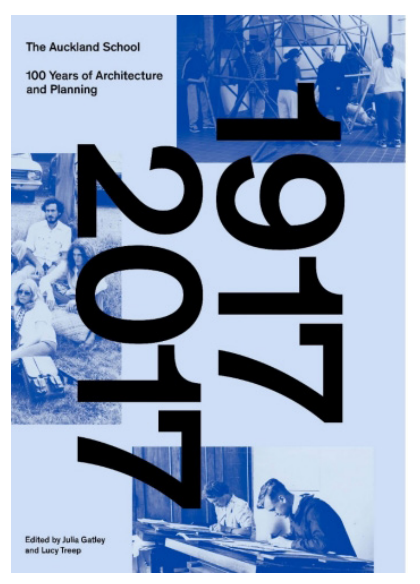

The Auckland School: 100 Years of Architecture and Planning is a commemorative account of a century of the School of Architecture and Planning at the University of Auckland. Written by staff members and published by the university, the book played an important part in recent centennial celebrations.

Anticipation of those celebrations have unavoidably marked its making, for the book is largely celebratory. As a whole, it is rarely critical or contentious. As such it accounts for much that happened over the century, but as a whole contends less. It eases us through the past, negotiating its way around things that could have been a stretch to the imagination if so desired. But it wasn't. This book knows its place in history.

Edited by Dr. Julia Gatley and Dr. Lucy Treep, The Auckland School includes contributions from Bill McKay, Andrew Barrie, and Elizabeth Aitken Rose. Each contributes a chapter leading chronologically through several decades of the school's evolution: Treep 1917-1940, Gatley 1940-1968, then McKay up to about 1980, and Barrie to around the turn of the century. Gatley returns to reflect on the school's current state, while Aitken-Rose slips in a piece about the Department of Planning.

The dispensing of the decades tends to align with either the contributor's specialist subject (i.e. Gatley and post-war modernism) or with the time spent at school (McKay and Barrie). Treep meanwhile was deep into the research, working her way back through archives and interviews. It was probably natural she took on the early years. And the engaging anecdotes and personal reflections of graduates and staff recalled throughout are presumably due to her many interviews. Judging by the extent of referencing, end noting, and indexing, it's clear the research for The Auckland School has been superbly conducted and curated.

The book's historical narrative generally favours depicting the school as a collection of buildings and biographies rather than a more precarious assortment of pedagogics. Through the decades we're introduced to the heads of department, key staff, and some of the more provocative students. The evolution of the school programme is discussed, but with less emphasis on its values or ideology, and a more sustained concern for the social context as something shaping what students learnt. 
When it comes to changes in the programme, on more than one occasion it's suggested charismatic staff harnessed student passions to foster revolt. In fact, there are stories of student activists in all decades pushing for staff appointments, better facilities, and changes to teaching methods. But invariably the agitation returns to the age-old question of the relationship between the academy and the profession. The Auckland School illustrates how this question emerges for each generation, with students lamenting the separation and wanting closer relations with practice, while academics celebrate the break and the intellectual freedom it affords. Or, of course, vice versa.

Through the decades we also witness the pressure that swelling numbers put on the school's accommodation. Considerable space is then given to tracing the history of school buildings. Having followed the foundation pupils down into the basement of the old Auckland Grammar School, we're then led down Symonds Street to the ClockTower arts building. From here it's across to the Remuera rentals and then back to the army huts in Symonds Street, before scattering amongst a slew of old buildings. Discontented with this shambles, the staff seize the day and we're welcomed into Doc Toy's early version of the vital "design theatre", then the short-lived-but-legendary brick, steel, and timber studios of the mid-tolate 1970s, and finally KRTA's "bent" building-first occupied in 1978 and still the school's home.

Aside the sense of duty to give voice to many of the gems collected in research, it's likely other forces-overt or otherwise-have shaped the story. The Auckland School is the product of careful and valuable research, but the close ties between the publisher, the subject, and its subjects necessarily raise questions about the book's place as native content. And it raises questions about what limitations were placed on the research and the contributors' ability to set it to work without fear or favour. In this dilemma and beneath the criticism of the book accounting for much but contending little lies a more haunting question-one of presence.

Michael King posed a question of presence in his History of New Zealand. He described how he had shaken the hand of someone who had shaken of someone who had shaken the hand of Sir George Grey. For King, this experience helped explain how close he felt to momentous events and key characters in local history. When writing, he said, he was confronted by vivid memories of things that felt so very close to his own lifetime.

In addition to the idea of history in Aotearoa being something vividly remembered, there is another moral to all of King's handshaking. It points to how local history is something ready-to-hand and something that has its ups and downs. For whilst there's the wonder of being so close to the past, there's the complication of trying to get beyond arm's-length with one's subject in order to be able to appreciate its broader historical presence.

If, due to the vagaries of life, only a handshake or two separates the historian from someone of significant historical import, then what of the reader? What's their relationship to the historical subject? It could be very close. And what of the opportunity for the historian and the reader to together step away? The question of presence is therefore a question for both the historian and the reader. To appreciate a subject's historical presence, it can be important to step out of its immediate presence. But the historian must lead the way. 
King anticipates the effects of presence on writing and suggests other historians should too. Their step away needs to be deliberate, forceful, and embedded in the very structure of the work in order to have effect.

The Auckland School names both a place and an educational experience that has a vivid presence in many people's memories. And these memories are, for the most part, living memories. A centenary is not long when measured in terms of architectural generations. Where we are now is very close to where it all began. Indeed, using the delightful list of academic appointments published at the back of the book it, didn't take long to work out I could go one better than King's triple-shake. I only needed two-having shaken the hand of someone who had shaken the hand of Cyril Knight, holder of the school's inaugural Chair.

It's useful to think about The Auckland School in terms of a question of presence; as a question of the presence of this school amidst a broader history of architectural education. And while the book is about a school it is, like much local history, also about how the editors and contributors chose to address the complications of being close to their subject. To what extent did they anticipate its effect?

John Dickson once characterized the Auckland School as a place where architectural education turned around contentious things. At Auckland, you struggled to surmount the difficulties and dangers of architecture. You were here to study architecture in a way that stretched the imagination and the intellect. I was told there were other places to go if I wanted to practice architecture.

If the Auckland School can be said to have a presence, then it may turn around this contentious idea. And this is not just a recent phenomenon. It's not an '80s post-modern challenging of grand narratives. The school is too young for this to be deemed a recent effect. Or rather, if you're only talking about 100 years, then everything is recent.

John Dickson shook hands with Doc Toy who shook hands with Cyril Knight. All these educators stretched the intellect. A history of the Auckland School could therefore quickly lead us back to the beginning of something contentious.

Each chapter in The Auckland School has snippets of debate, like that around the bent-building's design and who claims authorship-Dickson, Toy, Gordon Smith, Alan Wild or Ian Reynolds. I've seen many of an exchange of views on this. But while it's something of importance to those close-at-hand to the project, it doesn't really lead the reader to an appreciable thesis about the school as a place of education.

What has perhaps been let slip here is the opportunity for the writers to contend something about the school's historical presence and in so doing remember the school in a more consequential way. That opportunity was perhaps let slip by a missed step-that deliberate and forceful step away from the school's presence, a step that needed to be embedded in the book's structure.

Studying history at Auckland was always difficult. During my time it was a basic tenet that one did not structure an account chronologically. There was resistance to its neat division of the subject under investigation, its emphasis on the rhythms of continuity that could occlude critical enquiry, and the latent inwardness of its focus-your historical subject seems to affirm time's continuity and in turn affirm the narrative structure, so there's little motivation to step away and look beyond it. It's a structure that can ease you through the past. 
The school's history and theory staff lived this conviction, obliging their lectures and papers find structure elsewhere. They practiced what Andrew Leach characterises as thematic history, one examining relationships between architectural activity and other kinds of historical activity. Whether it was architecture and politics, or architecture and representation, or architecture and memory-the thematic approach tended to pair architecture with what Leach called an "external corollary". It promotes thinking at the borders of architecture and offers a way of stepping away from your subject in order to critique it.

As a student this was hard. Having abandoned chronology, it became a stretch to conceive of a narrative line through to the past. But that was the point. You were led away and had to think your way back. You had to contend with what else your subject could be aside from something that changed in time. In fact, you often had to contend with what your subject actually was.

Criticism can be leveled at both chronological and thematic approaches. But a thematic bias is known to incite a forceful step away. When the subject matter anticipates the need for such a step, and for the historian to lead the way, then it must seriously be considered as the model for structuring the narrative. In this respect, one wonders how different The Auckland School could have been if its structure was not chronologically marking time's passing, but instead contending pedagogical questions around architectural education. Perhaps we could have been led to contend that the Auckland School is not so much buildings and biographies, but more education. 